\title{
The Use of Platelet-Rich Plasma for Treatment of Tenodesmic Lesions in Horses: A Systematic Review and Meta-Analysis of Clinical and Experimental Data
}

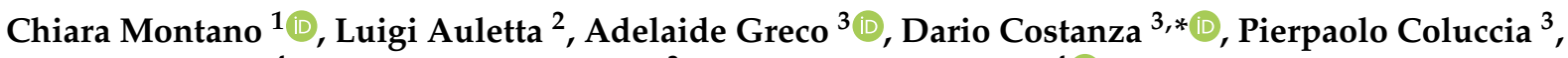 \\ Chiara Del Prete ${ }^{4}$, Leonardo Meomartino ${ }^{3}$ and Maria Pia Pasolini ${ }^{4}$ (i) \\ 1 Veterinary Teaching Hospital, School of Veterinary Medicine, University of Córdoba, 14004 Córdoba, Spain; \\ c.montano@hotmail.it \\ 2 Institute of Biostructure and Bioimaging, National Research Council (IBB CNR), Via T. De Amicis 95, \\ 80145 Napoli, Italy; luigi.auletta@yahoo.it \\ 3 Interdepartmental Centre of Veterinary Radiology, University of Napoli "Federico II", Via Federico Delpino 1, \\ 80137 Napoli, Italy; adegreco@unina.it (A.G.); pierpaolo.coluccia@unina.it (P.C.); meomarti@unina.it (L.M.) \\ 4 Department of Veterinary Medicine and Animal Production, University of Napoli "Federico II", \\ Via Federico Delpino 1, 80137 Napoli, Italy; chiara.delprete@unina.it (C.D.P.); pasolini@unina.it (M.P.P.) \\ * Correspondence: dario.costanza@unina.it
}

check for

updates

Citation: Montano, C.; Auletta, L.; Greco, A.; Costanza, D.; Coluccia, P.; Del Prete, C.; Meomartino, L.; Pasolini, M.P. The Use of Platelet-Rich Plasma for Treatment of Tenodesmic Lesions in Horses: A Systematic Review and Meta-Analysis of Clinical and Experimental Data. Animals 2021 11, 793. https://doi.org/10.3390/ ani11030793

Academic Editor: Alessandro Spadari

Received: 8 February 2021

Accepted: 9 March 2021

Published: 12 March 2021

Publisher's Note: MDPI stays neutral with regard to jurisdictional claims in published maps and institutional affiliations.

Copyright: (c) 2021 by the authors. Licensee MDPI, Basel, Switzerland. This article is an open access article distributed under the terms and conditions of the Creative Commons Attribution (CC BY) license (https:// creativecommons.org/licenses/by/ $4.0 /)$.
Simple Summary: Tenodesmic injuries are key problems for sport horses. Several therapies have been developed over the years, including platelet-rich plasma (PRP), an autologous product that should stimulate tissue regeneration with its high concentration of growth factors. Nowadays, there are conflicting reports concerning the effect of PRP in tenodesmic lesions. The aim of our systematic review was to determine the effect of PRP on tendons and ligaments healing through a meta-analysis, a process to determine consensus from across published studies. The meta-analysis is the quantitative component of a systematic review, a statistical synthesis of the published data about a topic. We selected studies that evaluate PRP therapy in vitro or in vivo, most of which had a high risk of bias. The results found there is no evidence that PRP enhances the healing of tendon and ligament injuries. In the future, further unbiased, blinded, and controlled studies are needed to clarify the efficacy of this platelet concentrate in the treatment of equine tendon and ligament injuries.

Abstract: The use of platelet-rich plasma (PRP) to enhance tenodesmic lesion healing has been questioned over the years. The aim of this study was to evaluate current literature to establish the effectiveness of PRP for treating tenodesmic lesions through a systematic review, in accordance with the PRISMA guidelines, and a meta-analysis. Studies comparing PRP with placebo or other treatments for horses with tenodesmic injuries or evaluated PRP effect on tendon and ligament explants were included. Outcomes were clinical, ultrasound, histologic, molecular evaluation, and adverse effects. Two authors independently extracted data and assessed each study's risk of bias. Treatment effects were evaluated using risk ratios for dichotomous data, together with 95\% CI. Data were pooled using the random-effects model. The quality of the evidence for each outcome was assessed using GRADE criteria. Twenty-four trials met inclusion criteria for systematic review, while fifteen studies were included in the meta-analysis. Results showed no significant differences in the outcomes between PRP and control groups. Finally, there is no definitive evidence that PRP enhances tendons and ligaments healing. Therefore, there is a need for more controlled trials to draw a firmer conclusion about the efficacy of PRP as a treatment for tenodesmic lesions in the horse.

Keywords: DDFT; equine; growth factors; healing; ligament; platelet concentrate; PRP; SDFT; SL; tendon 


\section{Introduction}

Tendon and ligament injuries are a serious career-compromising disease and a major cause of lameness, reduced performance, and premature retirement in horses of every discipline and aptitude [1-3]. Tendons tend to heal slowly, forming disorganized and collagen-rich scar tissue, with inferior mechanical properties compared to intact tendons [4]. Thus, reinjury is frequent $[5,6]$, and rational intervention strategies to prevent it is crucial to improve horse welfare and racing career longevity [7]. Over the years, many new conservative and surgical therapies were studied to treat these injuries. However, none of them provide a complete restoration of the anatomical and functional integrity of the injured tissues $[1,5,6,8]$.

Slow healing and mechanically inferior scars have been attributed to the poor vascularization and scarcity in progenitor cells of the tendon tissue [9]. Knowledge concerning tendon repair stimulated research regarding the application of regenerative therapies, aimed to restore the normal structure and biomechanics of the tissues using autologous blood derivatives such as platelet-rich plasma (PRP) and mesenchymal stem cells (MSCs), both in human and veterinary medicine [10-17].

Platelets in PRP can release several growth factors and induce the production of antiinflammatory cytokines, enhancing hemostasis, promoting the regeneration of tissue cells and stroma through different ways, and accelerating tissue repair [18-20]. The biological effects of PRP include an increase in type I collagen production, the proliferation of tenocytes, neovascularization, increased resistance, and a better organization and alignment of the fibers [9]. As PRP mechanism of action is still unclear, preparation standards and methods have not been unified, and its clinical efficacy is still controversial [21].

Clinical case series, experimental animal studies, placebo-controlled studies of naturally occurring injuries, and in vitro and ex vivo studies evaluated the effects of PRP in the horse. Systematic PRP evaluation for repairing tendon and ligament injuries may provide a scientific reference for treatment and clinical application strategies. Indeed, although in human and veterinary medicine several systematic reviews and meta-analyses have been subsequently published [3,15,21-29], it is still not clear which product or combination of substrates is most appropriate related to individual cases. Due to the variety of lesions and products, clinical studies would require large numbers, with economic and ethical concerns [30-32]. Thus, we decided to include in vitro and ex vivo studies in the meta-analysis, assuming a good standardization of the procedures compared to clinical trials.

The aim of this study was to elucidate this controversial issue, conducting a systematic review and meta-analysis of in vivo and in vitro studies about PRP efficacy to assess the effects (benefits and harms) of platelet-rich therapies for treating tenodesmic injuries in horses.

\section{Materials and Methods}

\subsection{Criteria for Considering Studies for This Review}

The systematic review was performed in accordance with the PRISMA (Preferred Reporting Items for Systematic Reviews and Meta-Analyses) statement [33], while the meta-analysis was performed using the program Review Manager 5.3 (Review Manager (RevMan) (Computer program) Version 5.3. Copenhagen: The Nordic Cochrane Centre, The Cochrane Collaboration, 2014).

The research was carried out between August 2019 and December 2020. A comprehensive literature search addressing PRP use in tendon and ligament injuries in horses was conducted for all the studies published in English, Portuguese, Spanish, and Italian language between 2000 and 2020. Two of the authors (MPP and CM) were involved in the studies' research. Disagreements were resolved by discussion or by arbitration by a third author (LA).

Search inclusion criteria were the presence of terms such as "PRP", "platelet-rich plasma", "tendon", "ligament", "horse", and "equine" in full manuscript, abstract, title, and keywords of publication searched on web search engines that index the full text or 
metadata of scholarly literature (e.g., Pubmed, Worldcat, Wide Science, Google Scholar, and Scopus).

Studies were excluded from the systematic review and meta-analysis process if they evaluated species other than horses, use another biomaterial and/or substance with PRP, use PRP in lesions different than ligament and tendon injuries.

Because of their scarcity, clinical trials were included independently of their level of evidence or design and without differentiating studies that have a control group from studies that do not have one.

\subsection{Data Extraction and Management}

Two authors (MPP and CM) independently extracted data using a pre-piloted data extraction form. When necessary, a third author (LA) was involved in solving any disagreement. For each trial included in the systematic review, the following data were extracted: year of publication, authors, journal of publication, type of intervention, treated tissue, studies classification such as in vivo or in vitro studies, randomized controlled trials (RCTs) or not (No-RCTs), controlled laboratory study (CLS), sample size, control group, outcome measurements, main results (positive, negative, neutral), adverse events, and bias.

\subsection{Types of Studies and Participants}

We included RCTs, No-RCTs, randomized controlled experimental trials, nonrandomized controlled experimental trials, and CLS, comparing platelet-rich therapy with placebo for musculoskeletal soft tissue injuries in adult horses or cultured cells from tendon and ligament explants.

The treatments in the studies were performed in horses affected by injuries of the Superficial Digital Flexor Tendon (SDFT), Deep Digital Flexor Tendon (DDFT), or Suspensory Ligament (SL). Laboratory studies were performed culturing SDFT and SL explants in medium added with PRP.

We place no restrictions in diagnostic methods or criteria used by individual studies, duration of the injury, follow-up period, and evaluation of the outcome.

\subsection{Types of Interventions}

We considered studies where platelet-rich therapies were the only treatment or additional to conservative therapy. Such studies compared platelet-rich therapy with no platelet-rich therapy or placebo. There was no restriction based on the number of procedures or injections and treatment dosage.

\subsection{Types of Outcome Measures}

We categorized the outcome as positive, negative, or neutral effects.

Improvement of the lameness degree and ultrasonographic appearance, return to the same/higher level of competition, high concentration of anti-inflammatory molecules, low concentration of proinflammatory factors, low reinjury rate, and realignment of collagen fibers at the histological examination were considered as positive effects. The opposite ones were negative outputs. The absence of difference in the evaluated outputs between the control group and the treated group or between PRP-group and data obtained from previous studies were neutral effects. First, an overall effect was evaluated, regardless of the outcomes assessed in the study. Second, histologic, ultrasonographic, and biomolecular outcomes examined in multiple studies were separately evaluated. Local and systemic adverse effects of platelet-rich therapy (or placebo) administration (including pain, swelling, infection, and anaphylactic reaction) were recorded.

\subsection{Measures of Treatment Effect and Assessment of Heterogeneity}

Risk ratios with $95 \%$ confidence intervals (CI) for dichotomous outcomes were presented. 
Heterogeneity between studies was quantified using the $\mathrm{I}^{2}$ statistic. An $\mathrm{I}^{2}$ value $>75 \%$ to indicate high heterogeneity was chosen [34]. Values of $p<0.05$ were considered significant.

\subsection{Risk of Bias}

The risk of bias of the selected studies was presented according to the PRISMA guidelines [33], and trials were assigned as having a high or low risk of bias. Together with the analysis of the clinical trials and experimental studies' results, this information was used to verify a possible association between bias and the trial's output.

\section{Results}

\subsection{Systematic Review}

Figure 1 shows how the studies were included. A total of 2883 articles were identified after the initial electronic and manual research. Of the 453 articles screened, we selected only 24 that respect the inclusion criteria. Selected studies are reported and numbered in Table 1.

From the selected clinical trials, three were classified as RCTs $[3,35,36]$ (study ID in Table 1: 3, 10,11); the other seven studies were classified as CLS [31,37-41] (study ID in Table 1: 7, 13, 14, 20-22).

Seven studies [3,31,37-41] (study ID in Table 1: 3, 7, 13, 14, 20-22) of the twentyfour included in this review described in vitro investigations, and the remaining seventeen $[30,35,36,42-55]$ originated from in vivo experiments.

Most of the trials studied the effect of PRP on tendons [30,31,36,37,40,43-45,47,48,51,55] (study ID in Table 1: 2, 4-7, 9, 11, 12, 14, 17, 21, 24); fewer articles analyzed its efficacy on ligaments [35,39-41,46,50,53,54] (study ID in Table 1: 8, 10, 16, 19, 20-23), and five of them $[3,38,42,49,52]$ (study ID in Table 1: 1, 3, 13, 15, 18) examined its influence in the healing of lesions of both SDFT and SL. Twenty-two out of twenty-four studies reported positive effects by PRP in tendinitis and desmitis treatment, whereas in one study [35] (study ID in Table 1: 10), no difference between control and treated groups was reported. Similarly, Estrada et al. [47] (study ID in Table 1: 9) conclude that the blood-concentrated injected during the proliferative phase of healing in surgically induced superficial digital flexor tendon (SDFT) core lesions have a minor effect on tendon's healing when ultrasonographic, biochemical, biomechanical, and histological characteristics were compared with the control group.

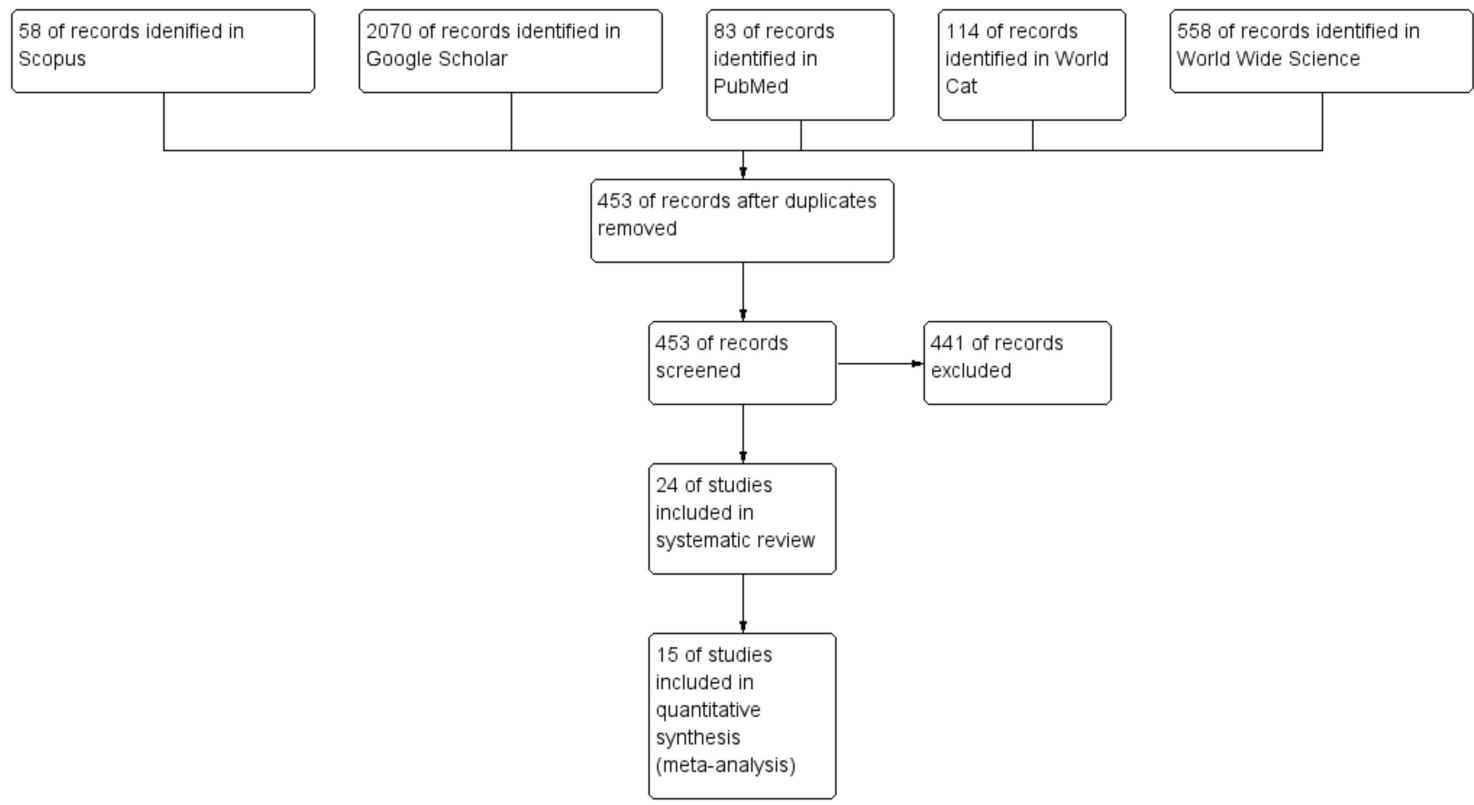

Figure 1. Flowchart for identification of published studies. Review Manager (RevMan 5.3). 
Table 1. Different sources of bias present in the studies included in the systematic review.

\begin{tabular}{|c|c|c|c|c|c|c|c|c|}
\hline $\begin{array}{l}\text { Study } \\
\text { ID }\end{array}$ & Study & $\begin{array}{l}\text { Random } \\
\text { Sequence } \\
\text { Generation } \\
\text { (Selection } \\
\text { Bias) }\end{array}$ & $\begin{array}{l}\text { Allocation } \\
\text { Conceal- } \\
\text { ment } \\
\text { (Selection } \\
\text { Bias) }\end{array}$ & $\begin{array}{l}\text { Blinding of } \\
\text { Participants } \\
\text { and Personnel } \\
\text { (Performance } \\
\text { Bias) }\end{array}$ & $\begin{array}{l}\text { Blinding of } \\
\text { Outcome } \\
\text { Assessment } \\
\text { (Detection } \\
\text { Bias) }\end{array}$ & $\begin{array}{l}\text { Incomplete } \\
\text { Outcome } \\
\text { Data } \\
\text { (Attrition } \\
\text { Bias) }\end{array}$ & $\begin{array}{l}\text { Selective } \\
\text { Reporting } \\
\text { (Report- } \\
\text { ing } \\
\text { Bias) }\end{array}$ & $\begin{array}{c}\text { Risk of } \\
\text { Bias }\end{array}$ \\
\hline 1 & Argüelles, 2008 & - & - & - & - & + & + & $\uparrow$ \\
\hline 2 & Bazzano, 2013 & - & - & - & - & + & + & $\uparrow$ \\
\hline 3 & Bonilla-Gutiérrez, 2018 & - & - & - & - & + & + & $\uparrow$ \\
\hline 4 & Bosch,2010 & - & + & - & + & + & + & $\downarrow$ \\
\hline 5 & Bosch, 2011 (1) & - & + & - & + & + & + & $\downarrow$ \\
\hline 6 & Bosch, 2011 (2) & - & + & - & + & + & + & $\downarrow$ \\
\hline 7 & Boswell, 2014 & - & - & - & - & + & + & $\downarrow$ \\
\hline 8 & Castelijns, 2011 & - & - & - & - & + & + & $\uparrow$ \\
\hline 9 & Estrada, 2014 & - & - & + & - & + & + & $\downarrow$ \\
\hline 10 & Garrett, 2013 & - & + & - & - & + & + & $\downarrow$ \\
\hline 11 & Geburek, 2016 & - & + & - & - & + & + & $\downarrow$ \\
\hline 12 & Maia, 2009 & - & - & - & - & + & + & $\uparrow$ \\
\hline 13 & McCarrell, 2009 & - & - & - & - & + & + & $\uparrow$ \\
\hline 14 & McCarrell, 2012 & - & - & - & - & + & + & $\uparrow$ \\
\hline 15 & Rindermann, 2010 & - & - & - & - & + & + & $\uparrow$ \\
\hline 16 & Romagnoli, 2015 & - & - & - & - & + & + & $\uparrow$ \\
\hline 17 & Romero, 2017 & - & - & - & + & + & + & $\downarrow$ \\
\hline 18 & Scala, 2014 & - & - & - & - & - & + & $\uparrow$ \\
\hline 19 & Spadari, 2010 & - & - & - & - & + & + & $\uparrow$ \\
\hline 20 & Schnabel, 2007 & - & - & - & - & + & + & $\uparrow$ \\
\hline 21 & Schnabel, 2008 & - & - & - & - & + & + & $\uparrow$ \\
\hline 22 & Smith, 2006 & - & - & - & - & + & + & $\uparrow$ \\
\hline 23 & Waselau, 2008 & - & - & - & - & + & + & $\uparrow$ \\
\hline 24 & Zuffova, 2013 & - & - & - & - & + & + & $\uparrow$ \\
\hline
\end{tabular}

(+) source of bias; (-) absent source of bias; $(\uparrow)$ high risk of bias; $(\downarrow)$ low risk of bias.

The most striking feature that affects the quality of the clinical trials included in this review was the lack of a placebo control group in nine of twenty-four studies. The control group (another horse, the contralateral limb, another culture medium, or another treatment) was present in fifteen studies.

A small number of cases' enrollment was the second most frequent flaw, often highlighted by the same authors as their study's limitations.

Some studies [23,35,50,54,55] (study ID in Table 1: 10, 11, 16, 23, 24) selected horses from the patients referred to respective hospitals, while other trials do not specify the selection process. The age, sex, breed, and aptitude of the horses selected for the investigations differ in the same study and between different studies.

Most of the trials selected indicate PRP concentration and the methods employed for its preparation, as shown in Table 2.

Regarding PRP activation, three studies [48,54,55] (study ID in Table 1: 12, 23, 24) activated PRP: calcium was used in two studies [48,55] (study ID in Table 1: 12, 24) and trombine in one [54] (study ID in Table 1: 23). In the remaining studies, PRP was not activated. Operators blinding was absent in all studies except one [30] (study ID in Table 1: 4). Animals studied were unaware of the treatment they were subjected to, but the clinicians who administered PRP or placebo almost always knew what they were administering. Garrett et al. [35] (study ID in Table 1: 10) specifies how the operators were aware of what they were injecting into the lesion because PRP and placebo (usually saline solution) have a different appearance.

Concerning the follow-up, all in vivo trials described post-operative care and a rehabilitation program to which every horse was subjected.

To assess the effectiveness of the treatment, trials evaluated different outcomes, as shown in Table 3. 
Table 2. Techniques used for platelet-rich plasma (PRP) preparation and final platelet concentration in the studies included in the systematic review. In bold the studies included in the meta-analysis.

\begin{tabular}{|c|c|c|c|c|}
\hline Study & Commercial System & Centrifugation & Filtration & Platelet Concentration \\
\hline Arguelles, 2008 & & $\sqrt{ }$ & & $250 \times 10^{6}$ platelets $/ \mathrm{mL}$ \\
\hline Bazzano, 2013 & & $\sqrt{ }$ & & $540.000 \pm 98.000$ platelets $/ \mu \mathrm{L}$ \\
\hline Bonilla-Gutierrez, 2018 & & $\sqrt{ }$ & & N.D \\
\hline Bosch, 2010 & $\sqrt{ }$ & & & $639.7 \pm 103.2 \times 10^{9}$ platelets $/ \mathrm{L}$ \\
\hline Bosch, 2011 (1) & $\sqrt{ }$ & & & N.D \\
\hline Bosch, 2011 (2) & $\sqrt{ }$ & & & $3.8 \times$ hematic concentration \\
\hline Boswell, 2014 & & $\sqrt{ }$ & & $236.750 \pm 35.714$ platelets $/ \mu \mathrm{L}$ \\
\hline Castelijns, 2011 & & & $\sqrt{ }$ & $850 \pm 244 \times 10^{9}$ platelets $/ \mathrm{L}$ \\
\hline Estrada, 2014 & $\sqrt{ }$ & & & $162.0 \pm 43.6 \times 10^{3}$ platelets $/ \mu \mathrm{L}$ \\
\hline Garret, 2013 & $\sqrt{ }$ & & & $966.000 \pm 189.000$ platelets $/ \mu \mathrm{L}$ \\
\hline Geburek, 2016 & & $\sqrt{ }$ & & $892.37 \pm 364.7 \times 10^{3}$ platelets $/ \mu \mathrm{L}$ \\
\hline Maia, 2009 & & $\sqrt{ }$ & & $407.500 \pm 58.800$ platelets $/ \mu \mathrm{L}$ \\
\hline McCarrell, 2009 & $\sqrt{ }$ & & & $1 \times 10^{9}$ platelets $/ \mathrm{mL}$ \\
\hline McCarrell, 2012 & $\sqrt{ }$ & & & N.D \\
\hline Rindermann, 2010 & $\sqrt{ }$ & & & $160-197 \times 10^{9}$ platelets $/ \mathrm{L}$ \\
\hline Romagnoli, 2015 & & $\sqrt{ }$ & & $1045 \times 10^{3}$ platelets $/ \mu \mathrm{L}$ \\
\hline Romero, 2017 & & $\sqrt{ }$ & & $\begin{array}{c}263.3 \times 10^{3} \pm 99.9 \times 10^{3} \\
\text { platelets } / \mu \mathrm{L}\end{array}$ \\
\hline Scala, 2014 & & $\sqrt{ }$ & & $1 \times 10^{6}$ platelets $/ \mu \mathrm{L}$ \\
\hline Schnabel, 2007 & $\sqrt{ }$ & & & $395 \times 10^{3}$ platelets $/ \mu \mathrm{L}$ \\
\hline Schnabel, 2008 & $\sqrt{ }$ & & & N.D \\
\hline Smith, 2006 & & $\sqrt{ }^{*}$ & & 520.000 platelets $/ \mu \mathrm{L}$ \\
\hline Spadari, 2010 & & $\sqrt{ }$ & & 7-11 × hematic concentration \\
\hline Waselau, 2008 & $\sqrt{ }$ & & & $1.37 \cdot 10^{6} \pm 1.11 \times 10^{4}$ platelets $/ \mu \mathrm{L}$ \\
\hline Zuffova, 2013 & & $\sqrt{ }^{*}$ & & $466.5 \times 10^{9}$ platelets $/ \mathrm{L}$ \\
\hline
\end{tabular}

$(\sqrt{ })$ technique used for PRP preparation; $\left(^{*}\right)$ double centrifugation; (N.D) value not declared.

Table 3. Type of study, sample constitution, interventions applied, and outcomes considered in the studies involved in the systematic review. In bold: studies included in the meta-analysis.

\begin{tabular}{ccccc}
\hline Study & Type of Study & Sample & Interventions & Outcomes \\
\hline Argüelles, 2008 & No-RCTs & $\begin{array}{c}\text { Two horses with } \\
\text { tendinopathy of SDFT and } \\
\text { three horses with desmitis } \\
\text { of SL. }\end{array}$ & $\begin{array}{c}\text { Injection of } 5-8 \mathrm{~mL} \text { of PRP } \\
\text { into the lesion. }\end{array}$ & $\begin{array}{c}\text { Improvements in the ultrasonographic } \\
\text { aspect of the lesions, especially in SDFT } \\
\text { tendonitis, decreased degree of lameness } \\
\text { and response to flexion test. All horses } \\
\text { returned to their preinjury level of } \\
\text { performance }\end{array}$ \\
Bazzano, 2013 & No-RCTs & $\begin{array}{c}\text { Fifteen horses affected by } \\
\text { tendinitis of SDFT or } \\
\text { DDFT. }\end{array}$ & $\begin{array}{c}\text { Injection of } 0.5-5 \mathrm{~mL} \text { of } \\
\text { PRP into the lesion. }\end{array}$ & $\begin{array}{c}\text { The ultrasonographic aspect of tendons, } \\
50 \text { days after the PRP treatment, was } \\
\text { comparable to healthy tendons; all horses } \\
\text { showed clinical improvement. All the } \\
\text { patients returned to train and compete; } \\
\text { no reinjury occurred within } 12 \text { months } \\
\text { from the beginning of the treatment. }\end{array}$ \\
\hline
\end{tabular}


Table 3. Cont.

\begin{tabular}{|c|c|c|c|}
\hline Study & Type of Study & Sample & Interventions \\
\hline $\begin{array}{l}\text { Bonilla-Gutiérrez, } \\
2018\end{array}$ & RCTs & $\begin{array}{l}\text { SL and SDFT samples } \\
\text { from six horses. }\end{array}$ & $\begin{array}{c}\text { Four SL and } 50 \% \text { of } \\
\text { concentration. One SL and } \\
1 \text { SDFT did not receive any } \\
\text { treatment and were used } \\
\text { as a control group. }\end{array}$ \\
\hline Bosch, 2010 & No-RCTs & $\begin{array}{l}\text { Six horses with induced } \\
\text { lesions of the SDFT in } \\
\text { both forelimbs. }\end{array}$ & $\begin{array}{l}\text { Injection of } 3 \mathrm{~mL} \text { of PRP in } \\
\text { the lesion and } 3 \mathrm{~mL} \text { of } \\
\text { saline solution in the other } \\
\text { limb (placebo group). }\end{array}$ \\
\hline
\end{tabular}

Outcomes

The concentration of IL- $1 \beta$, TNF- $\alpha$, IL-4,

IL-1 receptor antagonist, PDGF- $\beta \beta$,

TGF- $\beta 1$, and HA released from incubated tendons and ligaments was higher in the PRP group than in the control group.

The concentration of collagen, GAGs, and number of cells was higher in the

PRP-treated tendons. The repair tissue in the PRP group showed a higher elastic modulus and breaking strength.

Histologically, the PRP-treated tendons had a better organization of the collagen network and signs of increased metabolic activity.

Blood flow, evaluated with CFD, was significantly higher in the PRP-treated group. The total number of blood vessels 24 weeks after lesion induction,

Bosch, 2011 (1) No-RCTs lesions of the SDFT in both forelimbs.
Injection of $3 \mathrm{~mL}$ of PRP in the lesion and $3 \mathrm{~mL}$ of saline solution in the other limb (placebo group).

determined with the Factor VIII staining, was significantly higher in the PRP-treated tendons.

The ultrasonographic tissue characterization showed an E-value significantly higher in PRP-treated tendons than the controls at weeks 2, 3, 5 and 8; the C-value in the PRP group became significantly higher from week

12. The B-value was very similar

Injection of $3 \mathrm{~mL}$ of PRP in the lesion and $3 \mathrm{~mL}$ of saline solution in the other limb (placebo group). lesions of the SDFT in both forelimbs.

throughout the experiment for both groups. These results suggest that the

PRP treatment accelerates the collagenous matrix organization into tendon bundles and their arrangement along the stress lines.

In the LR-PRP group, the concentration of PDGF- $\beta \beta$, TGF- $\beta 1$, COL1A1, and COMP was increased. The concentration of IL-1 $\beta$, MMP-3, and MMP-13, instead was decreased.

The lameness score showed a reduction in all of the treated patients. The ultrasonographic exam performed three months after the treatment showed a complete resolution of the lesion for 10 horses. Five horses returned to their previous level of work.

$2.5 \mathrm{~mL}$ of platelet
concentrate was injecte into the lesion. desmitis of SL.
Explants of SDFT cultured days.
Injection of $2.5 \mathrm{~mL}$ of PRP or saline solution into the lesion (placebo group). The treatment assignment was randomized, and the operator was not aware of what he was injecting. lesions of the SDFT of both fore- and hindlimbs.
The PRP-treated tendons presented a significantly lower concentration of GAGs when compared to the control group. Other compositional,

biomechanical, ultrasonographic, and histological parameters showed no significant differences.

Considering the number of races started and earnings in the following 2,3, and 4 years, most of the horses treated with PRP started at least one race during the 2nd racing year. No significant differences were found between groups regarding starts during the 3rd and 4th year of competition and earnings. 
Table 3. Cont.

\begin{tabular}{cccc}
\hline Study & Type of Study & Sample & Interventions \\
\hline Geburek, 2016 & RCTs & $\begin{array}{c}\text { Twenty horses with } \\
\text { tendinitis of the SDFT of } \\
\text { one or both forelimbs. }\end{array}$ & $\begin{array}{c}\text { Injection of } 3 \mathrm{~mL} \mathrm{of} \mathrm{PRP} \mathrm{or} \\
\text { saline solution (placebo } \\
\text { group) in the lesion. }\end{array}$
\end{tabular}

Lameness decreased significantly at 8 weeks in the PRP-treated group, at 12 weeks in the placebo group.

Ultrasonographically, there were no differences in the cross-sectional area between the two groups; $80 \%$ of the PRP-treated horses reached their previous or a higher performance level after 12 months compared to $50 \%$ in the control group. After 24 months, these proportions were $60 \%$ and $50 \%$, respectively.

\begin{tabular}{|c|c|c|c|c|}
\hline Maia, 2009 & No-RCTs & $\begin{array}{l}\text { Six horses with induced } \\
\text { lesions of the SDFT in } \\
\text { both forelimbs. }\end{array}$ & $\begin{array}{l}2.5 \mathrm{~mL} \text { of activated PRP } \\
\text { was injected in the right } \\
\text { forelimb, } 2.5 \mathrm{~mL} \text { of saline } \\
\text { solution was administered } \\
\text { in the left forelimb } \\
\text { (placebo group). }\end{array}$ & $\begin{array}{l}\text { Thirty-six days after induced lesions, the } \\
\text { histologic exam showed that injuries } \\
\text { under PRP treatment presented a more } \\
\text { uniform and organized tissue repair than } \\
\text { the placebo group. }\end{array}$ \\
\hline McCarrell, 2009 & CLS & Five horses. & $\begin{array}{l}\text { Tendons and ligaments } \\
\text { cells from treated horses } \\
\text { were cultured with PRP } \\
\text { and placebo. }\end{array}$ & $\begin{array}{l}\text { The PRP group has a higher } \\
\text { concentration of TGF-b1, PDGF-BB, } \\
\text { COL1A1, COL3A1, COMP, and a lower } \\
\text { expression of MMP-13. }\end{array}$ \\
\hline McCarrell, 2012 & CLS & Eight horses. & $\begin{array}{l}\text { Tendons were chopped } \\
\text { into explants and placed } \\
\text { into culture plates; then, } \\
\text { they were cultured with } \\
\text { standard PRP, } \\
\text { high-concentration PRP, } \\
\text { leukocyte-reduced PRP, } \\
\text { concentrated-leukocyte } \\
\text { PRP, or placebo. }\end{array}$ & $\begin{array}{l}\text { The expression of COMP and } \\
\text { COL1A1/COL3A1 ratio was increased in } \\
\text { the PRP groups, while the expression of } \\
\text { MMP-13 was decreased. }\end{array}$ \\
\hline Rindermann, 2010 & Case report & $\begin{array}{c}\text { Seven horses with } \\
\text { tendinitis of SDFT, DDFT } \\
\text { or with desmitis of inferior } \\
\text { check ligament. }\end{array}$ & $\begin{array}{l}\text { Injection of } 2-4 \mathrm{~mL} \text { of } \\
\mathrm{ACP} \text { into the lesion. }\end{array}$ & $\begin{array}{l}\text { All horses treated with platelet } \\
\text { concentrate returned to their previous } \\
\text { level of work; the ultrasonographic } \\
\text { aspect of tendons/ligaments improved. }\end{array}$ \\
\hline Romagnoli, 2015 & No- RCTs & $\begin{array}{l}\text { Twenty horses with } \\
\text { desmitis of SL. }\end{array}$ & $\begin{array}{l}\text { Injection of } 0.8-4 \mathrm{~mL} \text { of } \\
\text { PRP into the lesion. }\end{array}$ & $\begin{array}{l}\text { Twenty-four months after the treatment, } \\
\text { sixteen horses returned to their previous } \\
\text { activity, while four animals recidivated } \\
\text { in different regions of SL. }\end{array}$ \\
\hline Romero, 2017 & No-RCTs & $\begin{array}{l}\text { Twenty horses with } \\
\text { induced lesions in SDFT in } \\
\text { both forelimbs. }\end{array}$ & $\begin{array}{l}\text { Horses received } 7 \mathrm{~mL} \text { of } \\
\text { PRP or } 7 \mathrm{~mL} \text { Ringer's } \\
\text { lactate solution (placebo } \\
\text { group) in assigned } \\
\text { tendons } 1 \text { week after the } \\
\text { injury induction. }\end{array}$ & $\begin{array}{c}\text { In the PRP-group, ten weeks after the } \\
\text { treatment, there was a significant } \\
\text { reduction in FPS, CSA, and TES. } \\
\text { Furthermore, PRP-treatment was } \\
\text { associated with a better histopathological } \\
\text { outcome. }\end{array}$ \\
\hline Scala, 2014 & No- RCTs & $\begin{array}{l}\text { Ninety-nine horses with } \\
\text { tenodesmic lesions. }\end{array}$ & $\begin{array}{l}\text { Injection of PRP into the } \\
\text { lesion (the amount of } \\
\text { injected product varies } \\
\text { depending on the size of } \\
\text { the lesion). }\end{array}$ & $\begin{array}{l}\text { Complete clinical and ultrasonographic } \\
\text { healing was obtained in } 81 \% \text { of treated } \\
\text { horses; } 12 \% \text { had an improvement and } 7 \% \\
\text { a failure. }\end{array}$ \\
\hline Schnabel, 2007 & CLS & $\begin{array}{l}\text { Six horses with induced } \\
\text { lesions in SDFT in both } \\
\text { forelimbs. }\end{array}$ & $\begin{array}{l}\text { Cultures were established } \\
\text { by } 5 \text { tendon explants (two } \\
\text { replicates/group); culture } \\
\text { media were whole blood, } \\
\text { plasma, PRP, PPP, and } \\
\text { bone marrow aspirate at } \\
\text { different concentrations. }\end{array}$ & $\begin{array}{c}\text { Tendons cultured in PRP showed } \\
\text { enhanced COL1A1, COL3A1, and COMP } \\
\text { concentrations, with no increase in the } \\
\text { catabolic molecules like MMP-3 and } \\
\text { MMP-13. }\end{array}$ \\
\hline
\end{tabular}


Table 3. Cont.

\begin{tabular}{|c|c|c|c|c|}
\hline Study & Type of Study & Sample & Interventions & Outcomes \\
\hline Schnabel, 2008 & CLS & Six horses. & $\begin{array}{c}\text { Tendons were chopped } \\
\text { into explants; cultures } \\
\text { were established with five } \\
\text { explants/well of six-well } \\
\text { plates with two } \\
\text { replicates/treatment } \\
\text { group (defined by culture } \\
\text { medium)/horse. Culture } \\
\text { media were whole blood, } \\
\text { plasma, PRP, PPP, bone } \\
\text { marrow aspirate at } \\
\text { different concentrations. }\end{array}$ & $\begin{array}{l}\text { Tendons cultured in PRP showed an } \\
\text { enhanced concentration of COL1A1, } \\
\text { COL3A1, COMP, decorin, with no } \\
\text { concomitant increase in the catabolic } \\
\text { molecules such as MMP-3 and MMP-13. }\end{array}$ \\
\hline Smith, 2006 & CLS & Five horses. & $\begin{array}{l}\text { Cells from SL sections } \\
\text { were recollected and } \\
\text { cultured with acellular } \\
\text { bone marrow, PRP, equine } \\
\text { serum, fetal bovine serum, } \\
\text { and medium (placebo } \\
\text { group). }\end{array}$ & $\begin{array}{l}\text { There was an increase in mean COMP } \\
\text { production and mean H-Leucine } \\
\text { incorporation in ligaments treated with } \\
\text { PRP. }\end{array}$ \\
\hline Spadari, 2010 & No- RCTs & $\begin{array}{l}\text { Ten horses with desmitis } \\
\text { of SL. }\end{array}$ & $\begin{array}{c}\text { Injection of PRP into the } \\
\text { lesion. }\end{array}$ & $\begin{array}{l}\text { Nine horses showed an improvement in } \\
\text { the ultrasonographic aspect of the SL and } \\
\text { returned to the activity. }\end{array}$ \\
\hline Waselau, 2008 & No-RCTs & Nine horses. & $\begin{array}{l}\text { Injection of } 3 \mathrm{~mL} \text { of PRP } \\
\text { into the lesion. }\end{array}$ & $\begin{array}{l}\text { The number of starts and earnings } \\
\text { during the first and third year was lower } \\
\text { than earnings and starts during the year } \\
\text { before the injury. During the second year, } \\
\text { the number of starts and earnings was } \\
\text { higher. }\end{array}$ \\
\hline Zuffova, 2013 & No-RCTs & $\begin{array}{l}\text { Twenty-two horses with } \\
\text { tendinitis of SDFT. }\end{array}$ & $\begin{array}{l}\text { Injection of PRP into the } \\
\text { lesion (the amount of } \\
\text { injected product varies } \\
\text { depending on the size of } \\
\text { the lesion). }\end{array}$ & $\begin{array}{l}\text { Horses with acute lesions ran } 56 \% \text { of } \\
\text { races in the follow-up period, while } \\
\text { animals with chronic injuries ran } 30 \% \text { of } \\
\text { competitions. }\end{array}$ \\
\hline
\end{tabular}

ACP: autologous conditioned plasma; CFD: color flow Doppler; CLS: controlled laboratory study; COL1A1: alpha-1 type I collagen; COL3A1: alpha-1 type III collagen; COMP: cartilage oligomeric matrix protein; CSA: cross-sectional area; FPS: fibre pattern score; GAGs: glycosaminoglycans; HA: hyaluronic acid; IL-1 $\alpha$ : interleukin- $1 \alpha$; IL-1 $\beta$ : interleukin- $1 \beta$; IL-4: interleukin-4; LR-PRP: leukocyte-rich platelet-rich plasma; MMP-13: matrix metalloproteinase-13; MMP-3: matrix metalloproteinase-3; No-RCTs: not randomized controlled trial; PDGF- $\beta \beta$ : platelet-derived growth factor- $\beta \beta$; PPP: platelet-poor plasma; RCT: randomized controlled trial; SDFT: superficial digital flexor tendon; SL: suspensory ligament; TES: tendon echogenicity score; TGF- $\beta 1$ : Transforming growth factor- $1 \beta$; TNF- $\alpha$ : Tumor necrosis factor- $\alpha$.

No side effects have ever been reported following PRP administration: two studies $[35,48]$ (study ID in Table 1: 10,12) described a mild and transient inflammation of the tissues after the injection of the blood concentrate.

Risk of Bias of Selected Studies

Table 1 shows the risk of bias of every clinical trial included in the systematic review and meta-analysis. As shown, most of the studies that confirm PRP benefits for the treatment of tenodesmic lesions were associated with a high risk of bias.

\subsection{Meta-Analysis}

Only fifteen of twenty-four trials were included in the meta-analysis $[3,30,31,35,36,38-41,44,45,47,48,51,54]$. Studies testing stem cells or other biomaterials together with PRP or without a control group were excluded. Selected studies were reported in bold in Table 3.

Three trials were classified as RCTs [3,35,36] (study ID in Table 1: 3, 10, 11); in vitro studies were all classified as CLS.

The animals selected in the studies were horses of different age, breed, sex, and attitude; a horse treated with saline solution or with another treatment $[35,36]$ (study ID in Table 1: 10, 11), the contralateral limb of the same animal injected with saline 
solution [30,44,45,47,48,51] (study ID in Table 1: 4-6, 9, 12, 17), tissue explants incubated with a placebo [3,31,38-41] (study ID in Table 1: 3, 13, 14, 20-22), or other affected horses that did not receive any treatment [54] (study ID in Table 1: 23) were used as control groups.

All the studies highlighted PRP positive influence in the healing of tenodesmic lesions. One trial [35] (study ID in Table 1: 10) reported no difference in the healing process between lesions treated with PRP or saline solution, whereas the study by Estrada et al. [47] (study ID in Table 1: 9) suggested the blood concentrate had limited effects on healing.

Platelet concentrate has been tested on tendons in nine trials $[23,30,31,40,44,45,47,48,51]$ (study ID in Table 1: 4-6, 9, 11, 12, 14, 17, 21), on ligaments in five experiments $[35,39,41,54]$ (study ID in Table 1: 10, 20, 22, 23), and on both structures in two studies [3,38] (study ID in Table 1: 3, 13).

Figure 2 shows the forest plot describing the overall outcome of PRP treatment vs. control (efficacy of PRP vs. no efficacy). In Figure 3, a second forest plot compares the outcomes evaluated in multiple investigations (ultrasonography, histology, biomolecular concentration) to verifying if heterogeneity varies between groups.

The graphs show no significant difference between the PRP group and the control group (Figure 2: OR 50.98; 95\% CI 4.28-606.93; $p=0.002$ ); (Figure 3: OR 32.46; 95\% CI $3.43-306.68 ; p=0.002)$. Moreover, both graphs show a high heterogeneity of results (Figure 2: $\mathrm{I}^{2}=85 \% ; p<0.00001$. Figure $\left.3: \mathrm{I}^{2}=84 \% ; p<0.00001\right)$, confirming that involved studies differ from each other and standardization of the process is lacking.

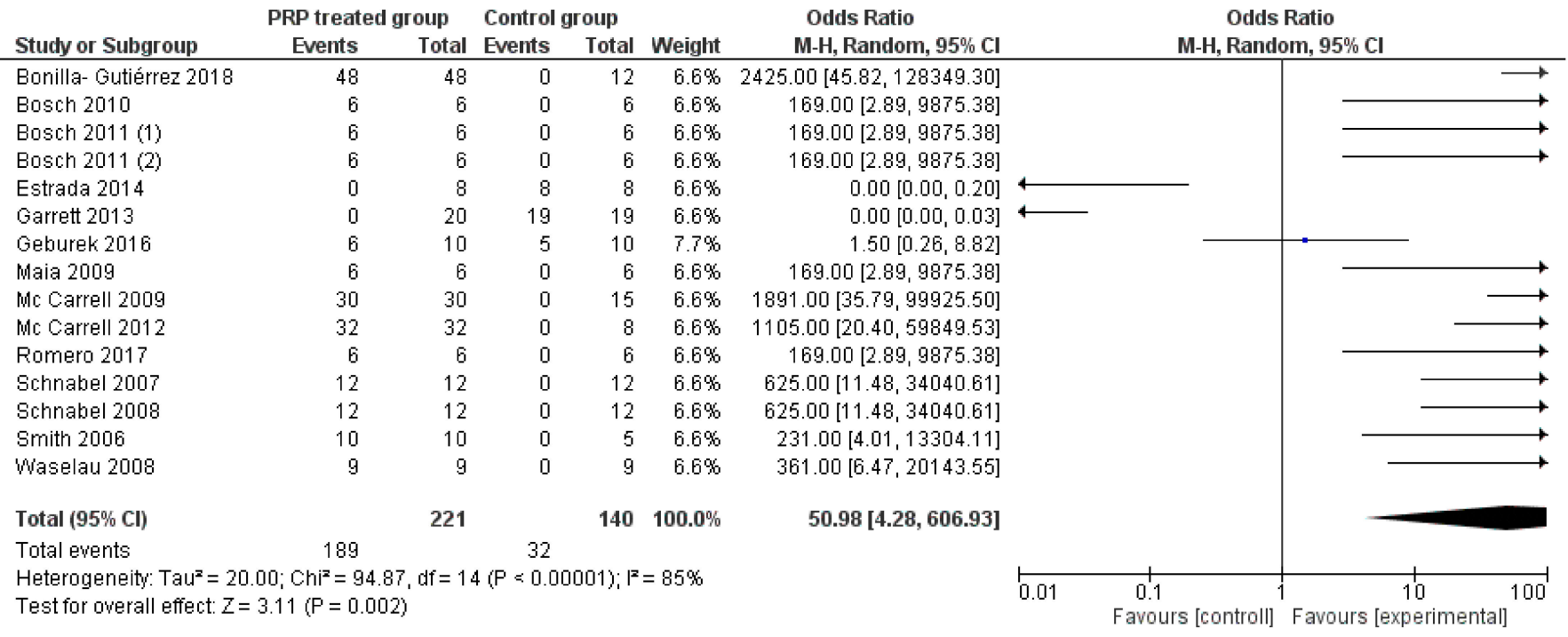

Figure 2. Forest plot representing successful outcomes of selected studies, using a meta-analytic approach based on the random-effects model. The squares represent the positive outcome of individual studies, with the whiskers corresponding to the $95 \%$ confidence interval $(95 \% \mathrm{CI})$. The diamonds correspond to the positive outcome of the study and $95 \% \mathrm{CI}$ of overall. 


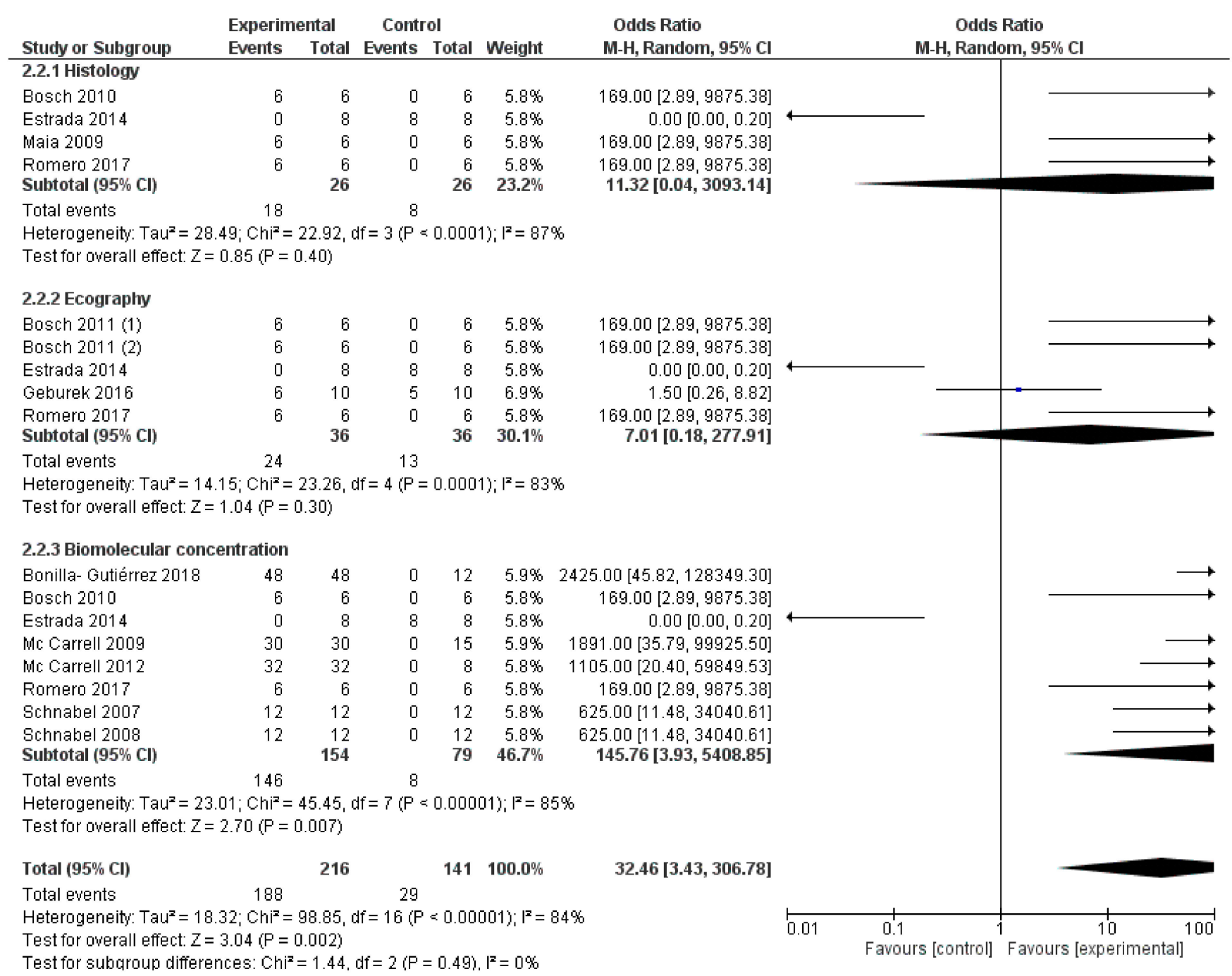

Figure 3. Forest plot representing successful outcomes of selected studies, divided into different subgroups, using a meta-analytic approach based on the random-effects model. The squares represent the positive outcome of individual studies, with the whiskers corresponding to the $95 \%$ confidence interval ( $95 \% \mathrm{CI})$. The diamonds correspond to the study's positive outcome and $95 \% \mathrm{CI}$ of every subgroup and overall.

\section{Discussion}

In the last two decades, the use of blood derivates for treating tenodesmic lesions has been increasing. As in human medicine, in the veterinary field, the most popular bloodproduct is PRP. In clinical practice, it is assumed that this blood concentrate promotes the healing process and reduces inflammation [56-60], but there is no agreement between researchers about this issue. Although most of the studies evaluated in this systematic review endorse PRP as an efficient treatment for tendon and ligament injuries, metaanalysis results do not confirm these conclusions due to the high risk of bias and the high heterogeneity. Indeed, a great number of uncontrolled or biased trials about PRP efficacy only suggest, but do not demonstrate, the beneficial effects of PRP [42,50,52,61]. The rigor of most clinical studies is weakened by the absence of a control group and the omission of histological evaluation. It would be unethical and could compromise welfare to treat an injured horse with a placebo [62], and economic constraints can limit the capacity to send sample tissues for histological examination. Therefore, the number of horses with owner consent for a controlled clinical trial is generally limited, and treatment and control groups lack high homogeneity [36]. 
The studies' methods were dissatisfied in most of the selected trials. The quality was inversely correlated with PRP performance in clinical trials; low-quality study design, with a high risk of bias, was most of the time associated with a positive performance of PRP. There were no studies with a low/moderate risk of bias in the systematic review and meta-analysis, as shown in Figures 4 and 5.

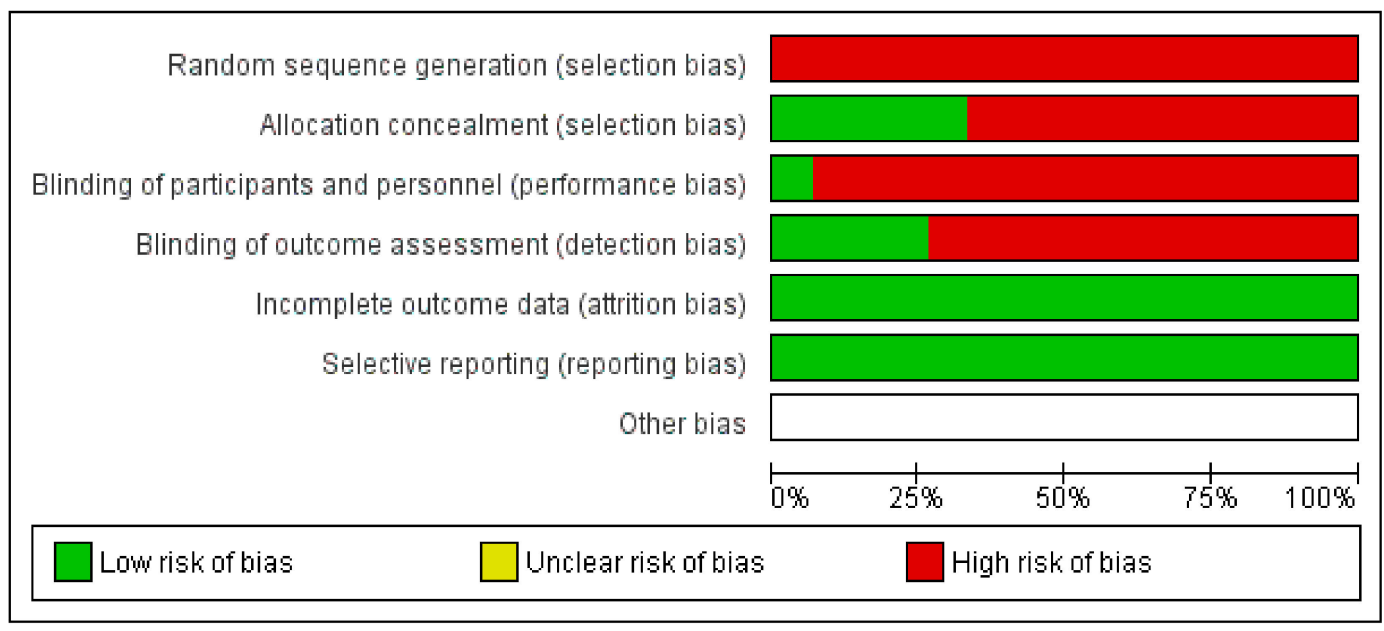

Figure 4. Risk of bias.

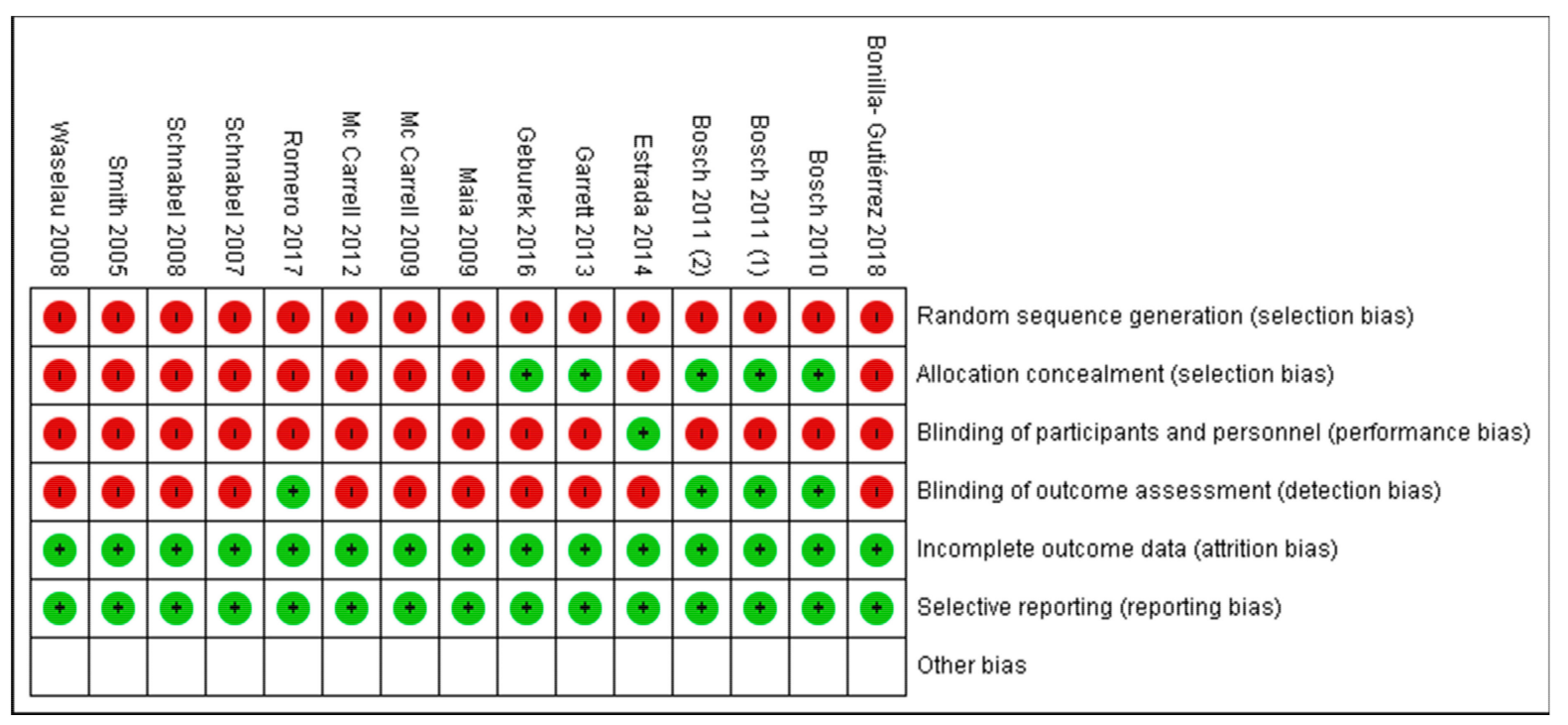

Figure 5. Summary of risk of bias.

The decision of including studies with a high risk of bias in the present systematic review and meta-analysis certainly increases the heterogeneity of the sample [63] but, on the other hand, also allows to establish a relationship between the design and the outcome of the study, as already suggested by Brossi et al. [15].

Only three trials included in the systematic review were RCTs, and one of these [35] (study ID in Table 1: 10) affirms that there was no evidence that PRP promotes the healing process. In this case, a rigorous methodology in the trial may be related to poor PRP performance [47].

Differently from recent human and veterinary reviews $[15,22,23,25-27,64]$, both in vivo and in vitro investigations were included in this study. Tendon and ligament explants cultured in PRP showed enhanced expression of matrix protein and growth factors with 
no concomitant increase in the catabolic molecules. These findings support in vivo investigations of PRP as an autologous treatment for tendon and ligament injuries [39,40].

The hypothesis was that in vitro studies have a better standardization of the methods and more objective outcomes. Indeed, in vitro trials provide a controlled environment of all the experiments [65], even though investigations were often carried out on healthy tendons and ligaments, which probably have a different response to PRP than injured ones [66]. Furthermore, all selected studies had a high risk of bias due to the absence of the operators' blinding. It was shown that in vitro PRP studies yield better results than clinical trials do, which indicates that experimental settings cannot perfectly mimic the conditions of natural tendon repair $[15,33]$. Thus, our hypothesis that including in vitro studies in the meta-analysis would have reduced the level of bias and increased the significance of the analysis was not confirmed.

There are many flaws in the selected trials: first, the absence of a control group. The control group is essential to isolate the independent variable's impact on the dependent variable, identifying different problems that can undermine the study's credibility [67]. The meta-analysis was conducted only on fifteen of the twenty-four examined trials because they were the only ones with a control group.

Second, another important flaw in the evaluated studies was the extreme variability of the preparation methods and characteristics of the platelet concentrate. As shown in Table 2, PRP was obtained using different techniques, and the final product had a platelet concentration that varies between trials. To allow a better comparison between the studies, we try to include only investigations that reported the platelet concentration and PRP preparation protocol.

The platelet concentrate could be produced by centrifugation (single or double), filtration, or commercial kits; authors could also choose if they activated the product or not $[31,46,68]$. Some of the selected clinical studies produced PRP by double centrifugation. They obtained good platelet concentrations, although it was reported that the technique causes significant alterations in platelet morphology and that it is more sensitive to small errors during preparation. The highest thrombocyte concentrations were obtained by filtration [46,69]. With both techniques, the outcomes reported a beneficial PRP effect in treating tenodesmic lesions: therefore, further studies are needed to clarify which methodologies are the most appropriate.

Furthermore, PRP was used in different concentrations in the selected trials: it has been shown that a $10 \%$ PRP solution has a greater biological effect on suspensory ligament explants than a 5\% solution [54], and this effect is still better at 100\% usage [40]. However, various PRP concentrations reached in these studies were sufficient to influence tendons and ligaments healing positively. It is recognized that lower platelet concentrations have minimal effects on tendons/ligaments healing, while too high concentrations may have negative effects on the tissue repair process [70]. McLellan et al. [64] suggest that growth factor concentration and platelet count are positively correlated and that higher concentrations of PRP solution promote a greater healing response. For this reason, the ideal preparation method should have a high collection efficiency and degree of repeatability, as commercial kits warrant.

Another controversial topic in the preparation of the PRP is the necessity to activate the product or not. The three studies that activated the product $[48,54,55]$ (study ID in Table 1: 12, 23,24) also reported good performance of PRP in the treatment of tenodesmic lesions, while the two studies $[35,47]$ (study ID in Table 1: 9, 10) that indicated the low efficacy of PRP did not proceed with activation; therefore, the question should be clarified through clinical and experimental studies.

The techniques of PRP administration were relatively similar: there was not a significant difference in the type of sedation and nerve blocks, the volume of product injected, the frequency of administration, and the materials used for injection between trials.

The absence of blinding was another limit in most studies. Figures 4 and 5 show the risk of bias of the trials submitted to meta-analysis; blinding reduces bias in the studies' 
outcome, so, if possible, practitioners evaluating the results should not be aware of the treatment. There is strong evidence that the absence of blinding produces exaggerated conclusions on the treatment's effect, especially when evaluating subjective outcomes (pain, lameness, pleasure, etc.) [71]. In addition to the blinding of the outcome assessor, all the trial participants should not be aware of the assigned intervention: animals were certainly unaware of the treatment they were subjected to, but most of the time, operators know what they were injecting in the lesion. Placebo (usually saline solution) and PRP have a different appearance, evident to the operators injecting into the lesion [35].

Another flaw was the low number of patients involved in the trials. Studies that enrolled a larger number of horses [35,52] (study ID in Table 1: 10,18) gave different opinions on the usefulness of PRP in the treatment of tenodesmic injuries, so we cannot correlate negative or positive effects to the size of the sample, but studies performed on few participants may be subject to type II errors.

The difference in the characteristics (age, sex, breed, and aptitude) of selected horses is another problem that does not allow to standardize PRP preparation because there is strong evidence that PRP is affected by intrinsic factors such as the breed, gender, and age [68]. Furthermore, the aptitude of the horse affected the outcome when this was evaluated as performance.

Selected clinical trials used PRP in acute, chronic, and experimentally induced tenodesmic lesions. Digital superficial flexor tendon (DSFT) and suspensory ligament (SL) of the fetlock were involved in different areas. Platelet-rich plasma gave unsatisfactory results in both SL [35] (study ID in Table 1: 10) and SDFT trials [47] (study ID in Table 1: 9). The tissue heterogeneity and the different stages of the disease do not provide precise PRP use recommendations based on the tissue damage [72]. Platelet-rich plasma should be used in acute lesions because there is only limited evidence that its injections are beneficial in chronic injuries [22].

The definition of the outcomes evaluated was flawless; the ways of presenting the outcomes, even though very different between them, were always objective and included: pain scales, concentration of growth factors, DNA, GAGs, pyrrole and collagen, evaluation of the elastic modulus of the treated tendons, and validated evaluation of the performance.

Most of the clinical trials suggested the use of a standardized rehabilitation/training program, which is a fundamental part for the complete resolution of tenodesmic injuries [73]. The exercise plan aims to provide an ascending regimen of activity that optimizes scar tissue function without causing damage to the tendon/ligament [74]. Exercise can be seen as a factor that, when used in combination with PRP treatment, improves healing of tendons and ligaments but can make it difficult to recognize if the outcomes depended only on PRP or the combination of those two elements.

To reduce the heterogeneity of the studies, a further meta-analysis of the subgroups sharing the same outcome was performed. Even so, this review did not show strong evidence that PRP improves the healing of tendon and ligament injuries in the horse, and there is currently no statistical basis for evaluating the effectiveness of PRP in clinical practice.

\section{Conclusions}

Although several studies seem to demonstrate that PRP has a beneficial effect on tendon and ligament healing without significant adverse effects; similar to previous studies, the present meta-analysis confirms that there is no definitive evidence of its effectiveness. Literature dedicated to the topic is quite extensive, but at the same time, it lacks standardization of study protocols, platelet separation techniques, and outcome measures.

The present review confirmed that poorly designed and biased studies that are not blinded or controlled and adopt inadequate outcome measures favored positive results.

In the near future, we suggest conducting studies that overcome those problems to obtain outcomes that might clarify this issue. 
Author Contributions: Conceptualization, M.P.P., C.M. and L.A.; Methodology, M.P.P., A.G. and L.A.; Software, C.M., L.A., D.C. and P.C.; Validation, M.P.P., L.A., A.G., L.M. and C.D.P.; Formal analysis, C.M., L.A., M.P.P. and D.C.; Investigation, M.P.P., C.M. and A.G.; Resources, M.P.P., C.M., A.G. and L.M.; Data curation, D.C., P.C. and C.M.; Writing-Original draft preparation, C.M., L.A., M.P.P. and P.C.; Writing-Review and editing, D.C., A.G., L.M., P.C. and C.D.P.; Visualization, D.C., P.C. and C.D.P.; Supervision, M.P.P., L.A., C.D.P. and L.M.; Project administration, A.G., D.C. and C.D.P.; Funding acquisition, M.P.P., A.G. and L.M. All authors have read and agreed to the published version of the manuscript.

Funding: This research received no external funding.

Institutional Review Board Statement: Not applicable.

Informed Consent Statement: Not applicable.

Data Availability Statement: The data presented in this study are available on request from the corresponding author.

Conflicts of Interest: The authors declare no conflict of interest.

\section{References}

1. Clegg, P.D. Musculoskeletal disease and injury, now and in the future. Part 2: Tendon and ligament injuries. Equine Vet. J. 2012, 44, 371-375. [CrossRef]

2. Trump, M.; Fürst, A.; Theiss, F. A Retrospective Study of the Prevalence of Injuries to the Suspensory Ligament, Digital Flexor Tendons and Associated Structures in a Non-Racehorse Referral-Hospital Population. Ph.D. Thesis, University of Zurich, Zurich, Switzerland, 2014.

3. Bonilla-Gutiérrez, A.F.; López, C.; Carmona, J.U. Regenerative Therapies for the Treatment of Tenodesmic Injuries in Horses. J. Equine Vet. Sci. 2019, 73, 139-147. [CrossRef]

4. Crevier-Denoix, N.; Collobert, C.; Pourcelot, P.; Denoix, J.M.; Sanaa, M.; Geiger, D.; Bernard, N.; Ribot, X.; Bortolussi, C.; Bousseau, B. Mechanical properties of pathological equine superficial digital flexor tendons. Equine Vet. J. Suppl. 1997, $23,23-26$. [CrossRef] [PubMed]

5. Palmer, S.E.; Genovese, R.; Longo, K.L.; Goodman, N.; Dyson, S. Practical management of superficial digital flexor tendinitis in the performance horse. Vet. Clin. N. Am. Equine Pract. 1994, 10, 425-481. [CrossRef]

6. Dyson, S.J. Medical management of superficial digital flexor tendonitis: A comparative study in 219 horses (1992-2000). Equine Vet. J. 2004, 36, 415-419. [CrossRef] [PubMed]

7. Lam, K.H.; Parkin, T.D.H.; Riggs, C.M.; Morgan, K.L. Descriptive analysis of retirement of Thoroughbred racehorses due to tendon injuries at the Hong Kong Jockey Club (1992-2004). Equine Vet. J. 2007, 39, 143-148. [CrossRef] [PubMed]

8. Reef, V.B. Superficial digital flexor tendon healing: Ultrasonographic evaluation of therapies. Vet. Clin. N. Am. Equine Pract. 2001, 17, 159-178. [CrossRef]

9. Guercio, A.; Di Marco, P.; Casella, S.; Russotto, L.; Puglisi, F.; Majolino, C.; Giudice, E.; Di Bella, S.; Purpari, G.; Cannella, V.; et al. Mesenchymal stem cells derived from subcutaneous fat and platelet-rich plasma used in athletic horses with lameness of the superficial digital flexor tendon. J. Equine Vet. Sci. 2015, 35, 19-26. [CrossRef]

10. Woo, S.L.Y.; Hildebrand, K.; Watanabe, N.; Fenwick, J.A.; Papageorgiou, C.D.; Wang, J.H.C. Tissue engineering of ligament and tendon healing. Clin. Orthop. Relat. Res. 1999, 312-323. [CrossRef] [PubMed]

11. Fortier, L.A.; Smith, R.K.W. Regenerative Medicine for Tendinous and Ligamentous Injuries of Sport Horses. Vet. Clin. N. Am. Equine Pract. 2008, 24, 191-201. [CrossRef] [PubMed]

12. Nixon, A.J.; Dahlgren, L.A.; Haupt, J.L.; Yeager, A.E.; Ward, D.L. With Collagenase-Induced Tendinitis. Am. J. Vet. Res. 2008, 69, 928-937. [CrossRef]

13. Barreira, A.P.B.; Alves, A.L.; Salto, M.E.; Arnorint, R.L.; Kohayagawa, A.; Menarim, B.C.; Mota, L.S. Autologous implant of bone marrow mononuclear cells as treatment of induced equine tendinitis. Int. J. Appl. Res. Vet. Med. 2008, 6, 46-54.

14. Textor, J. Autologous Biologic Treatment for Equine Musculoskeletal Injuries: Platelet-Rich Plasma and IL-1 Receptor Antagonist Protein. Vet. Clin. N. Am. Equine Pract. 2011, 27, 275-298. [CrossRef] [PubMed]

15. Brossi, P.M.; Moreira, J.J.; Machado, T.S.L.; Baccarin, R.Y.A. Platelet-rich plasma in orthopedic therapy: A comparative systematic review of clinical and experimental data in equine and human musculoskeletal lesions. BMC Vet. Res. 2015, 11, 1-17. [CrossRef] [PubMed]

16. Ortved, K.F. Regenerative Medicine and Rehabilitation for Tendinous and Ligamentous Injuries in Sport Horses. Vet. Clin. N. Am. Equine Pract. 2018, 34, 359-373. [CrossRef] [PubMed]

17. Im, G.-I.; Kim, T.-K. Stem Cells for the Regeneration of Tendon and Ligament: A Perspective. Int. J. Stem Cells 2020, 13, 335-341. [CrossRef]

18. Anitua, E.; Andia, I.; Ardanza, B.; Nurden, P.; Nurden, A.T. Autologous platelets as a source of proteins for healing and tissue regeneration. Thromb. Haemost. 2004, 91, 4-15. [CrossRef] [PubMed] 
19. Blair, P.; Flaumenhaft, R. Platelet $\alpha$-granules: Basic biology and clinical correlates. Blood Rev. 2009, 23, 177-189. [CrossRef] [PubMed]

20. Alsousou, J.; Thompson, M.; Hulley, P.; Noble, A.; Willett, K. The biology of platelet-rich plasma and its application in trauma and orthopaedic surgery: A review of the literature. J. Bone Jt. Surg. Ser. B 2009, 91, 987-996. [CrossRef] [PubMed]

21. Chen, Z.; Wu, Y.; Turxun, N.; Shen, Y.; Zhang, X. Efficacy and safety of platelet-rich plasma in the treatment of severe burns. Medicine 2020, 99, e23001. [CrossRef] [PubMed]

22. De Vos, R.J.; Van Veldhoven, P.L.J.; Moen, M.H.; Weir, A.; Tol, J.L.; Maffulli, N. Autologous growth factor injections in chronic tendinopathy: A systematic review. Br. Med. Bull. 2010, 95, 63-77. [CrossRef]

23. Geburek, F.; Stadler, P. Regenerative therapie von sehnen-Und banderkrankungen bei pferden: Ergebnisse der behandlung mit stammzellen, blutprodukten, gerüstsubstanzen und wachstumsfaktoren-Eine literaturübersicht und metaanalyse. Pferdeheilkunde 2011, 27, 609-625. [CrossRef]

24. Sheth, U.; Simunovic, N.; Klein, G.; Fu, F.; Einhorn, T.A.; Schemitsch, E.; Ayeni, O.R.; Bhandari, M. Efficacy of autologous platelet-rich plasma use for orthopaedic indications: A meta-analysis. J. Bone Jt. Surg. Ser. A 2012, 94, 298-307. [CrossRef] [PubMed]

25. Andia, I.; Latorre, P.M.; Gomez, M.C.; Burgos-Alonso, N.; Abate, M.; Maffulli, N. Platelet-rich plasma in the conservative treatment of painful tendinopathy: A systematic review and meta-analysis of controlled studies. Br. Med. Bull. 2014, 110, 99-115. [CrossRef] [PubMed]

26. Franchini, M.; Cruciani, M.; Mengoli, C.; Marano, G.; Pupella, S.; Veropalumbo, E.; Masiello, F.; Pati, I.; Vaglio, S.; Liumbruno, G.M. Efficacy of platelet-rich plasma as conservative treatment in orthopaedics: A systematic review and meta-analysis. Blood Transfus. 2018, 16, 502-513. [CrossRef]

27. Nauwelaers, A.K.; Van Oost, L.; Peers, K. Evidence for the use of PRP in chronic midsubstance Achilles tendinopathy: A systematic review with meta-analysis. Foot Ankle Surg. 2020. [CrossRef] [PubMed]

28. Allet, J.Z.L. How Effective are Injections of Platelet-Rich Plasma (PRP) for the Treatment of Sports Injuries: A Critical Review of the Literature. J. Sports Med. Doping Stud. 2012, 2. [CrossRef]

29. Moraes, V.Y.; Lenza, M.; Tamaoki, M.J.; Faloppa, F.; Belloti, J.C. Platelet rich therapies for musculoskeletal soft-tissue injuries. Cochrane Database Syst. Rev. 2012. [CrossRef]

30. Bosch, G.; Van Schie, H.T.M.; De Groot, M.W.; Cadby, J.A.; Van De Lest, C.H.A.; Barneveld, A.; Van Weeren, P.R. Effects of platelet-rich plasma on the quality of repair of mechanically induced core lesions in equine superficial digital flexor tendons: A placebo-controlled experimental study. J. Orthop. Res. 2010, 28, 211-217. [CrossRef] [PubMed]

31. McCarrel, T.M.; Minas, T.; Fortier, L.A. Optimization of leukocyte concentration in platelet-rich plasma for the treatment of tendinopathy. J. Bone Jt. Surg. Ser. A 2012, 94, e143. [CrossRef] [PubMed]

32. Ribitsch, I.; Baptista, P.M.; Lange-Consiglio, A.; Melotti, L.; Patruno, M.; Jenner, F.; Schnabl-Feichter, E.; Dutton, L.C.; Connolly, D.J.; van Steenbeek, F.G.; et al. Large Animal Models in Regenerative Medicine and Tissue Engineering: To Do or Not to Do. Front. Bioeng. Biotechnol. 2020, 8, 1-28. [CrossRef] [PubMed]

33. Moher, D.; Liberati, A.; Tetzlaff, J.; Altman, D.G. Preferred Reporting Items for Systematic Reviews and Meta-Analyses: The PRISMA Statement. PLoS Med. 2009, 6, e1000097. [CrossRef]

34. Deeks, J.J.; Higgins, J.P.; Altman, D.G. Analysing Data and Undertaking Meta-Analyses. In Cochrane Handbook for Systematic Reviews of Interventions; John Wiley \& Sons, Ltd: Chichester, UK, 2019; pp. 243-296.

35. Garrett, K.S.; Bramlage, L.R.; Spike-Pierce, D.L.; Cohen, N.D. Injection of platelet- and leukocyte-rich plasma at the junction of the proximal sesamoid bone and the suspensory ligament branch for treatment of yearling thoroughbreds with proximal sesamoid bone inflammation and associated suspensory ligament branch de. J. Am. Vet. Med. Assoc. 2013, 243, 120-125. [CrossRef] [PubMed]

36. Geburek, F.; Gaus, M.; van Schie, H.T.M.; Rohn, K.; Stadler, P.M. Effect of intralesional platelet-rich plasma (PRP) treatment on clinical and ultrasonographic parameters in equine naturally occurring superficial digital flexor tendinopathies-A randomized prospective controlled clinical trial. BMC Vet. Res. 2016, 12, 1-16. [CrossRef] [PubMed]

37. Boswell, S.G.; Schnabel, L.V.; Mohammed, H.O.; Sundman, E.A.; Minas, T.; Fortier, L.A. Increasing platelet concentrations in leukocyte-reduced platelet-rich plasma decrease collagen gene synthesis in tendons. Am. J. Sports Med. 2014, 42, 42-49. [CrossRef] [PubMed]

38. McCarrel, T.; Fortier, L. Temporal growth factor release from platelet-rich plasma, trehalose lyophilized platelets, and bone marrow aspirate and their effect on tendon and ligament gene expression. J. Orthop. Res. 2009, 27, 1033-1042. [CrossRef]

39. Schnabel, L.V.; Mohammed, H.O.; Miller, B.J.; McDermott, W.G.; Jacobson, M.S.; Santangelo, K.S.; Fortier, L.A. Platelet rich plasma (PRP) enhances anabolic gene expression patterns in flexor digitorum superficialis tendons. J. Orthop. Res. 2007, 25, 230-240. [CrossRef] [PubMed]

40. Schnabel, L.V.; Mohammed, H.O.; Jacobson, M.S.; Fortier, L.A. Effects of platelet rich plasma and acellular bone marrow on gene expression patterns and DNA content of equine suspensory ligament explant cultures. Equine Vet. J. 2008, 40, 260-265. [CrossRef] [PubMed]

41. Smith, J.J.; Ross, M.W.; Smith, R.K.W. Anabolic effects of acellular bone marrow, platelet rich plasma, and serum on equine suspensory ligament fibroblasts in vitro. Vet. Comp. Orthop. Traumatol. 2006, 19, 43-47. [PubMed] 
42. Arguelles, D.; Carmona, J.U.; Climent, F.; Munoz, E.; Prades, M. Autologous platelet concentrates as a treatment for musculoskeletal lesions in five horses. Vet. Rec. 2008, 162, 208-211. [CrossRef] [PubMed]

43. Bazzano, M.; Piccione, G.; Giannetto, C.; Tosto, F.; Di Pietro, S.; Giudice, E. Platelet Rich Plasma Intralesional Injection as Bedside Therapy for Tendinitis in Athletic Horse. Acta Sci. Vet. 2013, 41, 1-7.

44. Bosch, G.; Moleman, M.; Barneveld, A.; van Weeren, P.R.; van Schie, H.T.M. The effect of platelet-rich plasma on the neovascularization of surgically created equine superficial digital flexor tendon lesions. Scand. J. Med. Sci. Sport. 2011, 21, 554-561. [CrossRef] [PubMed]

45. Bosch, G.; René van Weeren, P.; Barneveld, A.; van Schie, H.T.M. Computerised analysis of standardised ultrasonographic images to monitor the repair of surgically created core lesions in equine superficial digital flexor tendons following treatment with intratendinous platelet rich plasma or placebo. Vet. J. 2011, 187, 92-98. [CrossRef] [PubMed]

46. Castelijns, G.; Crawford, A.; Schaffer, J.; Ortolano, G.A.; Beauregard, T.; Smith, R.K.W. Evaluation of a filter-prepared platelet concentrate for the treatment of suspensory branch injuries in horses. Vet. Comp. Orthop. Traumatol. 2011, 24, 363-369. [CrossRef] [PubMed]

47. Estrada, R.J.; Van Weeren, R.; Van De Lest, C.H.A.; Boere, J.; Reyes, M.; Lonita, J.C.; Estrada, M.; Lischer, C.J. Effects of

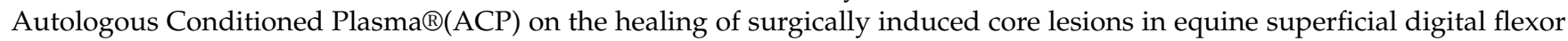
tendon. Pferdeheilkunde 2014, 30, 633-642. [CrossRef]

48. Maia, L.; de Souza, M.V.; Ribeiro Júnior, J.I.; de Oliveira, A.C.; Alves, G.E.S.; dos Anjos Benjamin, L.; Silva, Y.F.R.S.; Zandim, B.M.; Moreira, J.d.C.L. Platelet-Rich Plasma in the Treatment of Induced Tendinopathy in Horses: Histologic Evaluation. J. Equine Vet. Sci. 2009, 29, 618-626. [CrossRef]

49. Georg, R.; Maria, C.; Gisela, A.; Bianca, C. Autologous conditioned plasma as therapy of tendon and ligament lesions in seven horses. J. Vet. Sci. 2010, 11, 173-175. [CrossRef] [PubMed]

50. Romagnoli, N.; Rinnovati, R.; Ricciardi, G.; Lambertini, C.; Spinella, G.; Spadari, A. Clinical Evaluation of Intralesional Injection of Platelet-Rich Plasma for the Treatment of Proximal Suspensory Ligament Desmitis in Horses. J. Equine Vet. Sci. 2015, 35, 141-146. [CrossRef]

51. Romero, A.; Barrachina, L.; Ranera, B.; Remacha, A.R.; Moreno, B.; de Blas, I.; Sanz, A.; Vázquez, F.J.; Vitoria, A.; Junquera, C.; et al. Comparison of autologous bone marrow and adipose tissue derived mesenchymal stem cells, and platelet rich plasma, for treating surgically induced lesions of the equine superficial digital flexor tendon. Vet. J. 2017, 224, 76-84. [CrossRef] [PubMed]

52. Scala, M.; Lenarduzzi, S.; Spagnolo, F.; Trapasso, M.; Ottonello, C.; Muraglia, A.; Barla, A.; Strada, P. Regenerative medicine for the treatment of teno-desmic injuries of the equine. A series of 150 horses treated with platelet-derived growth factors. In Vivo 2014, 28, 1119-1124. [PubMed]

53. Spadari, A.; Ricciardi, G.; Rinnovati, R.; Romagnoli, N. Single Injection of Autologous Platelet Rich Plasma (PRP) in Suspensory Ligament Lesions in Horses: A Clinical Trial; European Society of Veterinary Orthopaedics and Traumatology: Cremona, Italy, 2011.

54. Waselau, M.; Sutter, W.W.; Genovese, R.L.; Bertone, A.L. Intralesional injection of platelet-rich plasma followed by controlled exercise for treatment of midbody suspensory ligament desmitis in Standardbred racehorses. J. Am. Vet. Med. Assoc. 2008, 232, 1515-1520. [CrossRef]

55. Zuffova, K.; Krisova, S.; Zert, Z. Platelet rich plasma treatment of superficial digital flexor tendon lesions in racing Thoroughbreds. Vet. Med. 2013, 58, 230-239. [CrossRef]

56. Zhang, J.; Middleton, K.K.; Fu, F.H.; Im, H.J.; Wang, J.H.C. HGF Mediates the Anti-inflammatory Effects of PRP on Injured Tendons. PLoS ONE 2013, 8, e67303. [CrossRef] [PubMed]

57. Lacci, K.M.; Dardik, A. Platelet-rich plasma: Support for its use in wound healing. Yale J. Biol. Med. 2010, 83, 1-9. [PubMed]

58. Thomopoulos, S.; Zaegel, M.; Das, R.; Harwood, F.L.; Silva, M.J.; Amiel, D.; Sakiyama-Elbert, S.; Gelberman, R.H. PDGF-BB released in tendon repair using a novel delivery system promotes cell proliferation and collagen remodeling. J. Orthop. Res. 2007, 25, 1358-1368. [CrossRef] [PubMed]

59. Anitua, E.; Andía, I.; Sanchez, M.; Azofra, J.; del Mar Zalduendo, M.; de la Fuente, M.; Nurden, P.; Nurden, A.T. Autologous preparations rich in growth factors promote proliferation and induce VEGF and HGF production by human tendon cells in culture. J. Orthop. Res. 2005, 23, 281-286. [CrossRef] [PubMed]

60. Kajikawa, Y.; Morihara, T.; Sakamoto, H.; Matsuda, K.I.; Oshima, Y.; Yoshida, A.; Nagae, M.; Arai, Y.; Kawata, M.; Kubo, T. Platelet-rich plasma enhances the initial mobilization of circulation-derived cells for tendon healing. J. Cell. Physiol. 2008, 215, 837-845. [CrossRef] [PubMed]

61. Torricelli, P.; Fini, M.; Filardo, G.; Tschon, M.; Pischedda, M.; Pacorini, A.; Kon, E.; Giardino, R. Regenerative medicine for the treatment of musculoskeletal overuse injuries in competition horses. Int. Orthop. 2011, 35, 1569-1576. [CrossRef] [PubMed]

62. Ricco, S.; Renzi, S.; Del Bue, M.; Conti, V.; Merli, E.; Ramoni, R.; Lucarelli, E.; Gnudi, G.; Ferrari, M.; Grolli, S. Allogeneic Adipose Tissue-Derived Mesenchymal Stem Cells in Combination with Platelet Rich Plasma are Safe and Effective in the Therapy of Superficial Digital Flexor Tendonitis in the Horse. Int. J. Immunopathol. Pharmacol. 2013, 26, 61-68. [CrossRef]

63. Glasziou, P.P.; Sanders, S.L. Investigating causes of heterogeneity in systematic reviews. Stat. Med. 2002, 21, 1503-1511. [CrossRef] [PubMed]

64. McLellan, J.; Plevin, S. Does it matter which platelet-rich plasma we use? Equine Vet. Educ. 2011, 23, 101-104. [CrossRef] 
65. Vadim, P.; Michelle, B.; Cen, Z.; Reichert, H.J. Chapter 4: In Vitro Models for Neuroelectrodes: A Paradigm for Studying Tissue-Materials Interactions in the Brain. In Indwelling Neural Implants: Strategies for Contending with the In Vivo Environment; Reichert, W.M., Ed.; CRC Press: Boca Raton, FL, USA, 2008; ISBN 978-0-8493-9362-4.

66. Wu, F.; Nerlich, M.; Docheva, D. Tendon injuries: Basic science and new repair proposals. EFORT Open Rev. 2017,2 , 332-342. [CrossRef] [PubMed]

67. Hunter, J.E.; Jensen, J.L.; Rodgers, R. The Control Group and Meta-Analysis. J. Methods Meas. Soc. Sci. 2014, 6, 3-21. [CrossRef]

68. Giraldo, C.E.; López, C.; Álvarez, M.E.; Samudio, I.J.; Prades, M.; Carmona, J.U. Effects of the breed, sex and age on cellular content and growth factor release from equine pure-platelet rich plasma and pure-platelet rich gel. BMC Vet. Res. 2013, 9. [CrossRef]

69. Tamimi, F.M.; Montalvo, S.; Tresguerres, I.; Blanco Jerez, L. A Comparative Study of 2 Methods for Obtaining Platelet-Rich Plasma. J. Oral Maxillofac. Surg. 2007, 65, 1084-1093. [CrossRef]

70. Elbackly, R.M.; Mastrogiacomo, M.; Cancedda, R. Bone Regeneration and Bioengineering. In Regenerative Medicine Applications in Organ Transplantation; Elsevier: Amsterdam, The Netherlands, 2014; pp. 783-797.

71. Schulz, K.F.; Grimes, D.A. Blinding in randomised trials: Hiding who got what. Lancet 2002, 359, 696-700. [CrossRef]

72. Engebretsen, L.; Steffen, K.; Alsousou, J.; Anitua, E.; Bachl, N.; Devilee, R.; Everts, P.; Hamilton, B.; Huard, J.; Jenoure, P.; et al. IOC consensus paper on the use of platelet-rich plasma in sports medicine. Br. J. Sports Med. 2010, 44, 1072-1081. [CrossRef]

73. Gillis, C.L. Rehabilitation of Tendon and Ligament Injuries. Am. Assoc. Equine Pract. 1997, 43, 306-309.

74. Avella, C.S.; Smith, R.K.W. Diagnosis and Management of Tendon and Ligament Disorders. In Equine Surgery; Elsevier: Amsterdam, The Netherlands, 2012; pp. 1157-1179. 